\title{
STRATEGI HUMAS DALAM MEMBANGUN CITRA MADRASAH MENJADI MADARASAH UNGGULAN DI KOTA MALANG
}

\author{
Abie Maulana Al Givari \\ UIN Maulana Malik Ibrahim Malang \\ Abiemaulana1008@gmail.com
}

\begin{abstract}
This study aims to describe the public relations strategy in building the image of madrassas to be the leading madrassas in Malang. This research was conducted at MAN 1 Malang City. This research was conducted using a descriptive qualitative approach, and in collecting data researchers used interview techniques, observation and documentation studies. The main subjects in this study are public relations, principals, teachers and students. The results of this study are: 1) Public Relations publish activities to be carried out by MAN 1 Malang City and achievements achieved by MAN 1 Malang City to the public through online media 2) Public Relations collaborates with government agencies, education and non-educational institutions 3) Public Relations prepare bigh-quality graduates in accordance with the vision of MAN 1 Malang, namely "The realization of high-quality buman beings in the Humanist and Religious Science and Technology.
\end{abstract}

Keywords: public relations strategy, madrasa image. Flagship madrasa

\begin{abstract}
Abstrak: Penelitian ini bertujuan untuk mendeskripsikan strategi humas dalam membangun citra madrasah menjadi madrasah unggulan di Kota Malang. Penelitian ini dilakukan di MAN 1 Kota Malang. Penelitian ini dilaksanakan dengan menggunakan pendekatan kualitatif deskriftif, dan dalam pengumpulan data peneliti menggunakan tehnik wawancara, observasi dan studi dokumentasi. Subyek utama dalam penelitian ini adalah humas, kepala sekolah, guru dan siswa. Hasil penelitian ini adalah: 1) Humas melakukan publikasi atas kegiatan yang akan dilaksanakan oleh MAN 1 Kota Malang dan prestasi yang diraih oleh MAN 1 Kota Malang ke masyarakat melalui media online 2) Humas melakukan kerjasama dengan instansi pemerintah, pendidikan dan instansi nonpendidikan 3) Humas menyiapkan lulusan yang berkualitas tinggi sesuai dengan visi MAN 1 Kota Malang yakni “Terwujudnya Insan yang Berkualitas Tinggi dalam IPTEK yang Humanis dan Religius.
\end{abstract}

Kata Kunci: Strategi Humas, Citra Madrasah. Madrasah Unggulan

\section{PENDAHULUAN}

Era globalisasi sekarang ini, kontribusi dari lembaga pendidikan diharuskan mampu memberikan layanan yang berkualitas kepada masyarakat. Hal ini dikarenakan semakin berkembangnya kebutuhan masyarakat akan layanan pendidikan yang

Fondatia : Jurnal Pendidikan Dasar

Volume 4, Nomor 2, September 2020; 234-244

https://ejournal.stitpn.ac.id/index.php/fondatia 
berkualitas. Masyarakat yang sebagai pengguna jasa lembaga pendidikan saat ini lebih pintar dalam memilih lembaga pendidikan. Lembaga pendidikan sekarang ini diharapkan mampu menganalisis kebutuhan masyarakat sebagai pelanggannya dan lembaga pendidikan dituntut selalu melibatkan partisipasi masyarakat dalam pengelolaan pendidikan. ${ }^{1}$

Ditengah-tengah persaingan ketat antar lembaga pendidikan sekarang ini, masyarakat yang sebagai pelanggan pendidikan sudah cukup pintar dalam menganalisa sebuah lembaga pendidikan untuk menjadi tujuan untuk mendidik anakanaknya kedepan, pastinya masyarakat akan menilai atau melihat input, proses maupun output dari lembaga pendidikan tersebut, Oleh karena itu, setiap lembaga pendidikan harus mampu menganalisa kebutuhan masyarakat sebagai pelanggan pendidikan, ini dimaksudakan untuk mengambil perhatian msyarakat terhadap lembaga pendidikan yang dikelola, agar nantinya input yang masuk kedalamnya sesuai target yang di pasang oleh pejabat lembaga pendidikan tersebut.

Dilihat dari aspek prestasi di dalam negeri, NUN Madrasah khususnya madrasah swasta tidak menunjukkan peningkatan yang berarti dari tahun ke tahun. Dari dunia pekerjaan muncul penyesalan bahwasanya lulusan-lulusan yang memasuki dunia kerja masih belum memiliki kesiapan kerja yang baik. Lembaga pendidikan yang bermutu pada khususnya dipercayai dapat melahirkan output yang bermutu, output yang bermutu akan dapat dengan mudah menembus jenjang pendidikan di atasnya dan seterusnya sampai dalam rangka memasuki dunia kerja sebagaimana diharapkan. $^{2}$

Menurut data dari Departemen Agama RI Tahun 2016/2017, di Indonesia Terdapat 50.479 Madrasah yang terdiri dari madrasah Ibtidaiyah (MI), madarasah Tsanawiyah, dan madrasah Aliyah, dan Cuma 3.888 diantaranya yang menyandang status Negeri dan selebihnya masih swasta. Sementara itu sekolah yang berada dibawah Kementrian Pendidikan dan Kebudayaan (Kemendikbud) persentase jumlah

1 Zaenal Mukarom, Muhibudin Wijaya Laksana. Manajemen Public Relation Panduan Efektif Pengelolaan Hubungan Masyarakat. (Bandung, Pustaka Setia, 2019) h. 7

${ }^{2}$ Agus Maimun \& Agus Zaenal Fitri. Madarasag Unggulan Lembaga Pendidikan Alternatif Di Era Kompetitif. (Malang, UIN-Maliki Press, 2010) h. 12 
sekolah negri mencapai 55\% dari total 302.097 sekolah (SD, SMP, SMA). ${ }^{3}$ Dari jumlah yang terbilang kecil itu, hanya sebagaian kecil saja madrasah negeri yang mempunyai pendidikan kualitas/unggul. Madrasah yang unggul bisa kita lihat dari tujuan pendidikannya, siswa, kualifikasi dan kompetensi tenaga pendidik, desain kurikulum yang diterapkan, sarana-prasarana dan situasi lingkungan atau lebih simpelnya dilihat dari segi input, proses dan output madrasah tersebut.

Citra adalah sebuah penilaian terhadap sebuah lembaga. citra, dihasilkan melalui penilaian objektif masyarakat atas tindakan, perilaku, dan etika sebuah lembaga di tengah-tengah masyarakat. Citra merupakan kesan, perasaan, gambaran diri publik terhadap sebuah lembaga, kesan yang dengan sengaja diciptakan dari suatu objek, orang, atau organisasi. ${ }^{4}$

Dengan demikian madrasah yang unggul adalah madrasah yang mampu bersaing dan melakukan inovasi dari berbagai hal sehingga lembaga sekolah tidak akan ketinggalan dari lembaga sekolah lain, dan sekolah harus terus meningkatkan citra yang baik dimata masyarakat, sehingga nilai kepercayaan yang diberikan oleh masyarakat akan tetap tinggi terhadap lembaga sekolah tersebut, dan tujuan menjadi madrasah unggulan bisa tercapai sesuai yang di harapkan.

\section{METODE PENELITIAN}

Pada dasarnya penelitian ini dimaksudkan untuk menguraikan strategi humas dalam meningkatkan citra madrasah menjadi lembaga pendidikan yang unggul, untuk menggapai tujuannya, peneliti mesti turun langsung ke lokasi penelitian guna mendapatkan data-data yang diperlukan sebagai bahan untuk dianalisis oleh peneliti sehingga bisa memenuhi fokus penelitian yang sudah diajukan. Untuk memudahkan peneliti dalam pengambilan data maka peneliti menggunakan pendekatan kualitatif karena dalam penelitian kualitatif yang menjadi sumber utamanya adalah manusia dan menjadi instrument kuncinya adalah peneliti sendiri, dan hasil dari penelitian kualitatif

${ }^{3}$ http://www.jurnas.com/artikel/40565/Jumlah-Madrasah-Negeri-Cuma-Tujuh-Persen.

${ }^{4}$ Chusnul Chotimah. Strategi Humas Pesantren Sidogiri Dalam Membangun Citra Lembaga Pendidikan Islam. Volume 7, No 1. September 2012, ISLAMICA. h. 5 
ini menggunakan kata-kata atau pernyataan yang sesuai dengan kenyataan yang ada. Penelitian kualitatif adalah metode penelitian yang berlandaskan pada filsafat postpositivisme, digunakan untuk meneliti pada kondisi obyek yang alamiah yang dimana peneliti adalah sebagai instrument kunci. ${ }^{5}$

Penelitian ini dirancang dengan menggunakan jenis penelitian studi kasus yang dimana penelitian studi kasus adalah suatu model yang menekankan pada eksplorasi dari suatu system yang berbatas pada satu kasus atau beberapa kasus secara mendetail, disertai dengan penggalian data secara mendalam yang melibatkan beragam sumber informasi yang kaya akan konteks. ${ }^{6}$ Dengan rancangan studi kasus peneliti bisa berfokus mengekplorasi pada satu kasus, yakni strategi humas dalam meningkatkan citra lembaga madarasah menjdai lembaga madrasah unggulan dengan melakukakn penggalian data secara mendalam yang melibatkan berbagai sumber yang kaya akan konteks data yeng diperlukan.

Tehnik pengumpulan data kualitatif merupakan pengumpulan data-data yang bersifat deskriftif yaitu data berupa gejala-gejala hasil wawancara atau observasi yang dikatagorikan ataupun dalam bentuk dokumen-dokumen saat penelitian. Oleh karna itu, dalam metode penelitian kualitatif, data dikumpulkan dengan tehnik observasi, wawancara, dan dokumentasi.Pada pendekatan ini, peneliti dapat menggunakan berbagai pendekatan apakah mengambil data secara terbuka atau diketahui oleh informan atau secara tertutup, bergantung kepada kebutuhannya. ${ }^{7}$

Data yang akan dicari dalam penelitian ini adalah data primer dan data sekunder. Data primer yakni data yang dibuat oleh peneliti untuk maksud khusus menyelesaikan permasalahan yang sedang ditelitinya. ${ }^{8}$ Data primer adalah data utama dalam penelitian ini yaitu data mengenai bentuk citra yang dibangun, strategi humas dan tujuan pendidikan unggul. Data primer ini bersumber dari kepala sekolah, Waka Humas, dan wakil kepala lainnya. Sedangkan data sekunder yakni data pendukung data primer yakni beberapa dokumen yang ada di madrasah MAN 1 Kota Malang

${ }^{5}$ Sugiyono.Metode Penelitian PendidikanPendekatan Kuantitatif, Kualitatif, dan R\&D. (Bandung, Alfabeta, 2015) h. 15

${ }^{6}$ Haris Herdiansyah. Metodologi Penelitian Kualitatif. (Jakarta, Salemba Humanika, 2010) h. 76

7 Amir Hamzah. Metode Penelitian Kualitatif. (Malang, Literasi Nusantara Abadi, 2019) h. 75

${ }^{8}$ Sugiyono.Metode Penelitian Kuantitatif, Kualitatif, dan R\&D. (Bandung, Alfabeta, 2014) h. 137 
yang digunakan untuk melengkapi dan pendukung data primer sehingga dari datadata yang didapatkan saling memperkuat dan semakin akurat.

\section{HASIL DAN PEMBAHASAN}

Hasil dari penelitian ini menunjukkan bahwa Humas MAN 1 Kota Malang membangun citra madrasah menerapkan beberapa strategi antara lain:

1. Melakukan Publikasi: Publisitas adalah kegiatan yang harus dilakukan oleh setiap lembaga pendidikan guna memperkenalkan lembaganya kepada masyarakat umum. Tugas pokok humas adalah membuat emige positif lembaga di benak masyarakat, citra positif dapat terbangun jika masyarakat memiliki pandangan yang bagus terhadap sebuah lembaga pendidikan. Agar hal itu dapat tercapai, maka masyarakat harus mendapatkan keluasan informasi tentang lembaga pendidikan tersebut. Artinya, tidak ada keasalah pahaman informasi antara lembaga pendidikan dengan masyarakat. Kegiatan menyampaikan informasi disebut dengan publikasi. Jadi, publikasi adalah kegiatan mengenalkan lembaga pendidikan kepada khalayak umum sehingga kalayak umum mengenal lembaga pendidikan tersebut. ${ }^{9}$

Publisitas menjadi peluang humas dalam mengenalkan lembaganya kepada khalayak umum sehingga khalayak umum bisa mengenal lembaganya, dalam rangka membangun komunikasi sebuah lembaga pendidikan harus melaksanakan kegiatan-kegiatan setealah itu dilakukan kegiatan publisitas baik bersifat internal maupun eksternal. Dalam hal ini, Suryosubroto menjelaskan bahwasanya disekolah dikenal dengan adanya kegiatan publisitas kedalam dan ke luar organisasi. Kegiatan publisitas internal yaitu memberikan informasi kepada pihak lembaga/organisasi, sasarannya adalah warga sekolah yakni, guru, siswa, tenaga kependidikan dsb. Pada perinsipnya kegiatan internal bertujuan untuk memberikan penjelasan tentang kebijaksanaan penyelenggaraan dan pengembangan madrasah/sekolah, menampung saran dan pendapat warga sekolahyang berhubungan dengan pembinaan dan pengembangan madrasah,

${ }_{9}^{9}$ Rahmat Kriyantono, Public Relations Writing. (Jakarta, Kencana Prenada Media Group, 2013) 
memelihara hubungan harmonis sehingga terciptanya kerjasama antar semua elemen madrasah. ${ }^{10}$ Kegiatan publisitas internal dapat dibedakan atas kegiatan langsung yaitu dengan tatap muka dan kegiatan tidak langsung yaitu melalui media tertentu. Kegiatan langsung antara lain bisa melalui rapat guru, upacara sekolah, karyawisata dan penjelasan lisan diberbagai kesempatan. Sedangkan kegiatan tidak langsung penyampaiannya bisa melalui surat edaran, papan pengumuman atau madding sekolah.

Berdasarkan uraian diatas dapat dipahami bahwasanya kegiatan humas tidak terlepas dengan kegiatan publikasi. Kegiatan publikasi adalah hal yang wajib dilakukan oleh seorang humas untuk membangun citra positif di tengah-tengah masyarakat, sehingga masyarakat akan memiliki kepercayaan yang tinggi terhadap lembaga yang sedang dikelolanya.

\section{Menjalin Kerjasama}

Islam mengajarkan bahwasanya menjaling hubungan dengan sesama sangatlah penting, karena manusia adalah mahluk sosial yang tidak bisa hidup tanpa orang lain, maka sudah sepatut manusia selalu menjaga hubungannya baik dengan Allah sang pencipta Hablumminallab dan sesama manusia Hablumminanas. Sebagaimana yang firmankan oleh Allah SWT dalam Al-Qur'an surah Al-Hujurat ayat 13 yang berbunyi

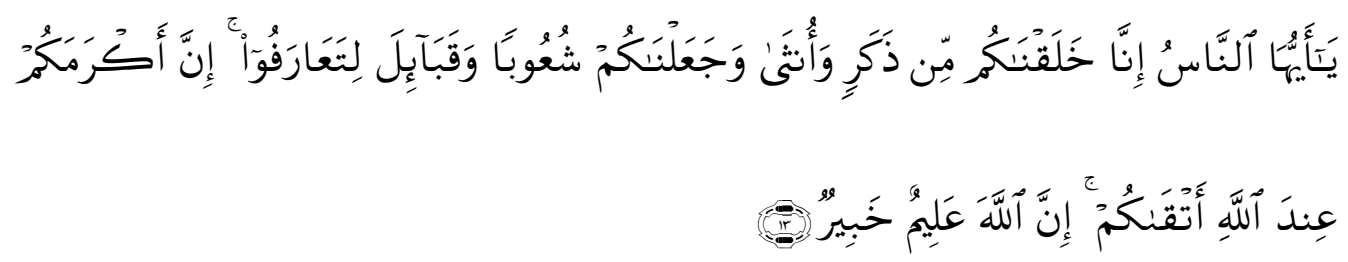

Hai manusia, Sesungguhnya Kami menciptakan kamu dari seorang laki-laki dan seorang perempuan dan menjadikan kamu berbangsa - bangsa dan bersuku-suku supaya kamu saling kenal-mengenal. Sesungguhnya orang yang paling mulia diantara kamu disisi Allah ialah orang yang paling taqwa diantara kamu.

${ }^{10}$ B. Suryobroto. Manajemen Pendidikan Di Sekolah. (Jakarta, PT Rineka Cipta, 2009) h 157 
Sesungguhnya Allah Maha mengetahui lagi Maha Mengenal. (Q.S. Al-Hujurat 49:13)

Dari ayat di atas dapat dipahami bahwasanya islam mengharuskan manusia untuk saling mengenal anatara sesama manusia, perkenalan ini dibutuhkan untuk saling menarik pelajaran dan pengalaman pihak lain, guna meningkatkan ketakwaan kepada Allah SWT. Manusia adalah mahluk mempunyai sifat sosial yang tidak bisa hidup tanpa bantuan dari orang lain, maka manusia mau atau tidak mau, tidak dapat dari melakukan kerjasam dengan orang lain, semakin banyak kebutuhan manusia, semakin sedikit pula kemampuan untuk memenuhinya, dan kita tidak bisa mengelak dari kebutuhan padata bantuan orang lain. Begitu pula dengan sebuah lembaga pendidikan, tidak akan bisa berkembang atau maju jika tidak melakukan hubungan kerjasama dengan pihak lain, sebuah madrasah sangat lah membutuhkan bantuan dari orang lain, baik itu bantuan berupa materi, pemikiran, maupun dukungan.

Berdasarkan uraian diatas bahwasanya humas MAN 1 Kota Malang melakukan hubungan kerjasama dengan berbagai pihak, baik dengan pihak orang tua, pihak masyarakat, seperti tokoh masyarakat, tokoh agama dsb, maupun dengan pihak instansi-instansi lain baik pemerintah maupun swasta, hal ini dilakukan selain untuk meningkatkan citra madrasah, yaitu untuk meningkatkan mutu dan kualitas SDM yang dimiliki oleh MAN 1 Kota Malang itu sendiri. Dalam peningkatan kualitas SDM MAN 1 Kota Malang menjalin hubungan kerjasama dengan banyak perguruan-perguruan tinggi, seperti UIN Maliki Malang, UMM, POLINEMA, ITS, dan juga MAN 1 Kota Malang menjalin hubungan kerjasma dengan Universitas luar negeri yakni Tokyo International University.

3. Menyiapkan Lulusan Yang Berkualitas Tinggi

Secara umum karakteristik Madrasah maju yaitu

a. mempunyai manajemen madrasah yang baik

b. Memiliki SDM yang berkompeten dalam bidangnya

c. Mempunyai Kelengkapan sarana dan prasarana 
d. bantuan pendidikan yang mememadai

e. Memiliki Keunggulan kualitas lulusan. ${ }^{11}$

Dilihat dari karakteristik madarasah unggulan diatas bahwasanya memiliki output atau lulusan yang berkualitas adalah hal yang harus dimiliki oleh setiap lembaga dikarenakan didalam UU sisidiknas No. 20 tahun 2003 BAB II Pasal 13 yang berbunyi Pendidikan nasional berfungsi mengembangkan kemampuan dan membentuk watak serta peradaban bangsa yang bermartabat dalam rangka mencerdaskan kehidupan bangsa, bertujuan untuk berkembangnya potensi peserta didik agar menjadi manusia yang beriman dan bertakwa kepada Tuhan Yang Maha Esa, Berakhlak Mulia, Sehat, Berilmu, Cakap, Kreatif, Mandiri, dan menjadi warga negara yang Demokratis serta Bertanggung jawab. ${ }^{12}$ Setiap lembaga pendidikan dituntut untuk mencetak generasi penerus bangsa yang memiliki keluasan ilmu pengetahuan dan mempunyai sikap-sikap religius yang tercantum dalam UU Sisdiknas No 20 tahun 20.

Pendidikan adalah wahana yang paling efektif untuk mencetak generasi generasi bangsa yang berkualitas di masa yang akan dating, pendidikan harus terus berbenah dari berbagai macam aspek, baik itu dari segi kurikulum, dari segi kualitas pendidik, kualitas sarana dan prasarana yang dapat menunjang pembelajaran peserta didik, budaya sekolah dsb. Hal ini dimaksudkan untuk sarana mencetak lulusan yang berkualitas. Dalam hal ini MAN 1 Kota Malang mempunyai Visi yang sangat jelas untuk mencetak generasi atau lulusan yang berkualitas, hal ini bisa kita lihat dalam tuangan visi dan misinya MAN 1 Kota Malang yakni "Terwujudnya insan yang berkualitas tinggi dalam IPTEK yang religius dan humanis". Dengan melihat misinya MAN 1 Kota Malang dapat disimpulkan bahwasanya MAN 1 Kota Malang ingin memiliki output yang berkualitas tinggi baik itu dalam bidang IPTEK maupun IMTAQ, dengan memiliki output yang berkualitas tinggi diharapkan mampu untuk membangun citra atau Nama besar lembaga di benak khalayak umum.

${ }^{11}$ Fuad Fachruddin, "Madrasah Model: Indikator Obyektif dan Operasionalnya", Jurnal Madrasah, Vol. 3, No. 3 (Jakarta: PPIM IAIN, 1998), 80

${ }^{12}$ https://kelembagaan.ristekdikti.go.id/wpcontent/uploads/2016/08/UU_no_20_th_2003. pdf 
Berdasarkan dari uraian diatas maka dapat disimpulkan bahwasannya pencitraan sekolah bukan dimaksudkan untuk mengemas ketidakbaikan sekolah menjadi terkesan baik, melainkan untuk mengemas dengan baik apa yang sudah dikerjakan oleh madrasah untuk disampaikan kepada Masyarakat. Ini diharapkan untuk membangun emage yang bagus di benak masyarakat sehingga masyarakat memberikan kepercayaan yang tinggi kepada madrasah untuk menyekolahkan anak-anaknya dikemudian hari. ${ }^{13}$

Dengan demikian, dari hasil analisis hasil penelitian, peneliti merumuskan strategi humas dalam membangun citra madrasah menjadi madrasah unggulan sebagai berikut:

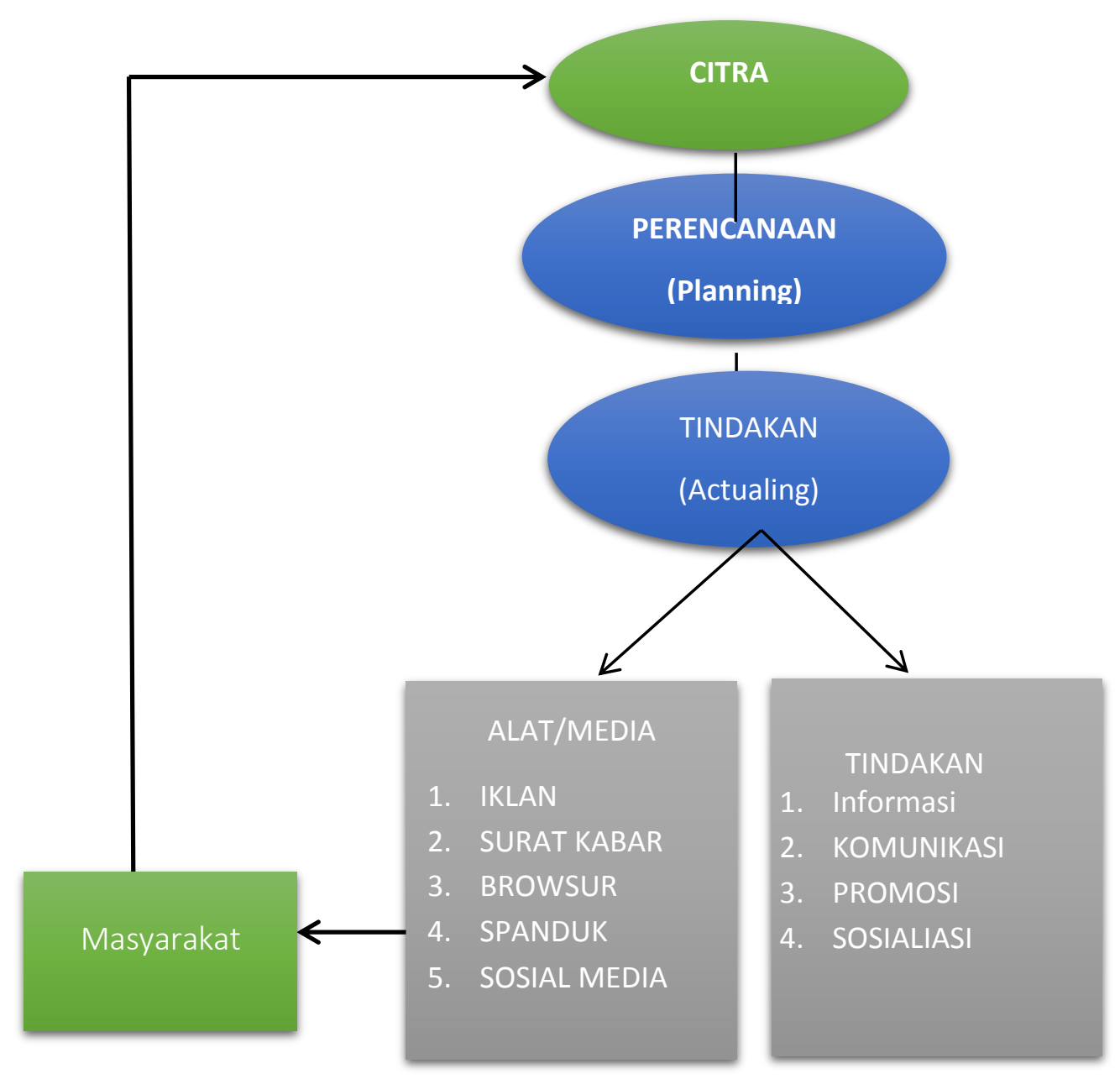

Gambar 1 Strategi Humas Membangun citra

13 Tutut Sholihah. Strategi Manajemen Humas Dalam Menciptakan School Branding Pada Sekolah Islam Terpadu. JMPI. Vol. 3, No 2, Desember, 2016. h. 4 


\section{KESIMPULAN}

Berdasarkan data yang telah dikumpulkan dan dilakukan analisin pembahasan tentang Strategi Humas dalam Membangun Citra MAN 1 Kota Malang menjadi Madrasah Unggulan di Kota Malang, maka dapat ditarik kesimpulan sebagai berikut:

1. Melakukan Publikasi

Humas MAN 1 Kota Malang selalu melakukan kegiatan Publikasi atas kegiatan-kegiatan madrasah yang akan dilaksanakan kepada masyarakat melalui beberapa media baik dengan menggunakan media online maupun melalui surat kabar atau Koran. Selain kegiatan Humas MAN 1 Kota Malang juga mempublikasi prestasi-prestasi yang diraih baik siswa, guru, maupun Madrasah itu sendiri, baik dalam bidang akademik maupun non akademik. Hal ini bertujuan agar masyarakat mengetahui kegiatan-kegiatan MAN 1 Kota Malang dan prestasi yang diraih oleh MAN 1 Kota Malang sehingga citra akan terbangun di benak masyarakat bahwasnya MAN 1 Kota Malang adalah Madrasah yang memiliki kualitas baik di bidang akademik maupun non akademik.

2. Menjalin Kerjasma

Selanjutnya strategi humas dalam membangun citra madrasah adalah dengan menjalin hubungan kerjasama dengan instasin luar baik dengan instansi pemerintah maupun dengan instasi lain maupun dengan masyarakat. Karena lembaga yang maju itu adalah lembaga yang bersinergi dengan lembaga lain. Hal ini bertujuan selain untuk meningkatkan potensi-potensi baik peserta didik maupun guru, menjalin kerjasam bertujuan untuk mendapatkan bantuan, baik bantuan itu bersifat materi maupun non materi, seperti dukungan, saran dsb. Sehingga MAN 1 Kota Malang bisa menjadi Madrsah unggulan di kota Malang

3. Menyiapkan Lulusan yang Berkualitas Tinggi

Strategi selanjutnya adalah memiliki lulusan yang berkualitas tinggi. Seperti yang telah dijelaskan sebelumnya bahwasanya MAN 1 Kota Malang mempunyai Visi yakni “Terwujudnya Insan Yang Berkualitas Tinggi Dalam IPTEK Yang Religius Dan Humanis". Dalam hal ini bahwasanya dengan mencetak lulusan yang berkualitas tinggi akan meciptakan citra atau persepsi di 
pikiran masyarakat umum bahwasanya MAN 1 Kota Malang adalah lembaga pendidikan unggul yang mampu mencetak luluasan yang berkualitas, sehingga citra MAN 1 Kota Malang akan terbangun di masyarakat bawasanya MAN 1 Kota Malang adalah Madrasah yang berkualitas.

\section{DAFTAR PUSTAKA}

Agus Maimun \& Agus Zaenal Fitri. Madarasag Unggulan Lembaga Pendidikan Alternatif Di Era Kompetitif. 2010, UIN-Maliki Press. Malang.

Amir Hamzah. Metode Penelitian Kualitatif. 2019. Literasi Nusantara Abadi, Malang.

B. Suryobroto. Manajemen Pendidikan Di Sekolah. 2009, PT Rineka Cipta, Jakarta.

Chusnul Chotimah. Strategi Humas Pesantren Sidogiri Dalam Membangun Citra Lembaga Pendidikan Islam. Volume 7, No 1. September 2012, ISLAMICA.

Fuad Fachruddin, "Madrasah Model: Indikator Obyektif dan Operasionalnya", Jurnal Madrasah, Vol. 3, No. 3 1998. PPIM IAIN. Jakarta.

Haris Herdiansyah. Metodologi Penelitian Kualitatif. 2010. Salemba Humanika. Jakarta, http://www.jurnas.com/artikel/40565/Jumlah-Madrasah-Negeri-Cuma-TujuhPersen.

https://kelembagaan.ristekdikti.go.id/wpcontent/uploads/2016/08/UU_no_20_th_ 2003.pdf.

Morissan. Manajemen Humas. 2014, Kencana Pranamedia Group, Jakarta.

Rahmat Kriyantono, Public Relations Writing. 2013, Kencana Prenada Media Group, Jakarta

Salusu, J. Pengambilan Keputusan Untuk Organisasi Profit dan Nonprofit. 1996, Grafindo Persada. Jakarta.

Sugiyono.Metode Penelitian Kuantitatif, Kualitatif, dan R\&DD. 2014. Alfabeta, Bandung.

Sugiyono.Metode Penelitian PendidikanPendekatan Kuantitatif, Kualitatif, dan R\&D. 2015 Alfabeta, Bandung.

Tutut Sholihah. Strategi Manajemen Humas Dalam Menciptakan School Branding Pada Sekolah Islam Terpadu. JMPI. Vol. 3, No 2, Desember, 2016.

Zaenal Mukarom, Muhibudin Wijaya Laksana. Manajemen Public Relation Panduan Efektif Pengelolaan Hubungan Masyarakat. 2019, Pustaka Setia. Bandung. 